1944, when Dr. Thomas Midgley, jun., vice-president of Ethyl Corporation, and known for his discovery of tetraethyl lead, becomes president, succeeding Dr. Per K. Frolich, director of the Chemical Division, Esso Laboratories, Standard Oil Development Company, Elizabeth, New Jersey. Dr. Marvel was recently awarded the 1944 William $H$. Nichols Medal of the New York Section of the American Chemical Society. He has made outstanding contributions to research on the structure of vinyl polymers, used as synthetic plastics, particularly in the production of transparent aircraft parts, as rubber substitutes, and as thickening and blending agents in the chemical manufacturing industry. He has also made important researches on the structure of polymers of sulphur dioxide and olefines, and has developed practical methods for preparing amino-acids.

\section{Wind and Bird-Migration}

Dr. Norman H. Joy (Field, Dec. 11, 1943) has published a short account of observations on birdmigration maintained almost continuously for four years at Dungeness, on the coast of Kent. This is useful work, of a kind not often undertaken so intensively. $\mathrm{He}$ has, in particular, noted the conditions of departure across the English Channel in autumn. As only selected observations are given, it is difficult to make a critical assessment of the conclusion that birds of certain species, for example, swallows, leave only when there is a confrary wind. The frequency with which birds are seen migrating against the wind has often been remarked. To some extent the impression may be exaggerated-birds flying across the wind (as Dr. Joy points out) have to head partially into it to correct their drift; and birds flying against the wind, at reduced speed in relation to the ground, remain longer under notice. In any event, it is open to question whether the relation between wind and a migratory movement is one of cause and effect, or whether they have a common origin in the general meteorological situation. Dr. Joy's suggestion that birds find a head wind advantageous because it gives them more lift is untenable: once it is airborne, a bird can derive no lift from the body of air within which it moves (assuming, for simplicity, that the current is horizontal and of uniform strength), except as a result of its own air speed.

\section{Poisonous Reptiles of the World}

THE Smithsonian Institution "War Background Studies", No. 10 is on the poisonous reptiles of the world, by Doris M. Cochran (Smithsonian Inst., 1943). It contains brief accounts of all the principal poisonous reptiles arranged in geographical groups, namely, the United States, Latin America, Europe and northern Asia, India and Malaya, Africa and Australia, New Guinea and the South Pacific Islands. The brochure is illustrated with seventeen plates, the first of which is coloured and most of which contain two species. There is also a small selected bibliography and an appendix dealing with first aid treatment, the preparation of antivenin and directions to collectors. From it medical officers should be able to identify any of the ordinary poisonous reptiles with which they are likely to be concerned even without previous knowledge of the group. It is obvious also that it will be useful to others than to those for whom it is particularly written.

\section{Fishes from Philippine Seas}

HeNRY W. Fowler has described many new fishes in his recent paper "Contributions to the Biology of the Philippine Archipelago and Adjacent Regions. Descriptions and Figures of New Fishes obtained in the Philippine Seas and Adjacent Waters by the United States Bureau of Fisheries Steamer Albatross" (U.S. National Museum, Bull. 100, 14, part 2. Smithsonian Institution, 1943). These belong to several families and form an appendix to the detailed reports on these groups of Albatross fishes. There are ten new genera, one new sub-genus, one new sub-family and twenty-two new species in this paper. Many of these fishes are of striking form, notably Calliurichthys lineathorax n.sp., with its enormously long caudal fin as long as all the rest of the fish. All the illustrations are excellent.

\section{The Night Sky in February}

FuLl moon occurs on Feb. 9d. 05h. 29 m. U.T., and new moon on Feb. 24d. 01h. $59 \mathrm{~m}$. The following conjunctions with the moon take place: Feb. 3d. 06h., Mars $7^{\circ}$ N. ; Feb. 4d. 07h., Saturn $3^{\circ}$ N.; Feb. 9d. 1lh., Jupiter $0.4^{\circ}$ S.; Feb. 2ld. 20h., Venus $1^{\circ} \mathrm{S} . ;$ Feb. 22d. 20h., Mercury $1^{\circ} \mathrm{S}$. The following occultations of stars brighter than magnitude 6 take place: Feb. 4d. 22h. 58.6m., 57 Ori. $(D)$; Feb. 5d. 03h. 23.6m., 64 Ori. $(D)$; Feb. 7d. 18h. 36·7m., $d^{1}$ Canc. $(D)$; Feb. 7d. 23h. 43·0m., $\theta$ Canc. $(D)$; Feb. 17d. 06h. 01-Im., $\eta$ Lib. $(R)$. The times refer to Greenwich and $D$ and $R$ refer to disappearance and reappearance respectively. Mercury rises at $6 \mathrm{~h}$. $28 \mathrm{~m}$. at the beginning of the month and at $6 \mathrm{~h} .44 \mathrm{~m}$. at the end of the month, and is too close to the sun to be favourably seen. Venus rises a little before $6 \mathrm{~h}$. throughout the month and is a conspicuous object in the morning hours. Mars can be seen through a good portion of the night, setting at $3 \mathrm{~h}$. $57 \mathrm{~m}$., $3 \mathrm{~h}$. $26 \mathrm{~m}$., and $2 \mathrm{~h} .56 \mathrm{~m}$. at the beginning, middle and end of the month. Jupiter is in opposition on Feb. 11 and can be seen throughout the night, setting at $8 \mathrm{~h}$. $21 \mathrm{~m}$. and $6 \mathrm{~h} .20 \mathrm{~m}$. at the beginning and end of the month. Saturn is a little east of Mars and sets about 15 minutes later than Mars in the middle of the month. At the beginning and end of the month Saturn sets at $4 \mathrm{~h}$. $35 \mathrm{~m}$. and $2 \mathrm{~h} .42 \mathrm{~m}$. The planet is stationary on Feb. 20.

\section{Announcements}

WE regret to announce that Dr. W. W. C. Topley, F.R.S., secretary since 1941 of the Agricultural Research Council, and formerly professor of the division of bacteriology and immunology in the University of London, died on January 21, aged fifty-seven.

The Council of the Royal Aeronautical Society has elected Group Captain F. Whittle a fellow of the Society; such an election is a specialdistinction in recog. nition of work of great importance in aeronautics.

Mr. Atruee, Lord President of the Council, has announced that the Government has appointed the following committee to consider and make recommendations as to the development of television after the War : Lord Hankey (chairman); Sir Noel Ashbridge and Mr. Robert Foot, B.B.C.; Sir Raymond Birchall and Sir Stanley Angwin, General Post Office ; Mr. Harvey, Treasury ; Sir Edward Appleton, Department of Scientific and Industrial Research ; and Prof. J. D. Cockcroft, Ministry of Supply. 